\title{
TEXTO\& CONIEXTO
ENFERMAGFM
}

TEXT \& CONTEXT NURSING TEXTO \& CONTEXTO ENFERMERÍA

\section{IT POSSIBLE TO DIE AT HOME? ANALYSIS OF THE BRAZILIAN AND FRENCH SCENARIOS}

Franciele Roberta Cordeiro' 1 Maria Henriqueta Luce Kruse ${ }^{2}$

${ }^{1}$ Universidade Federal de Pelotas, Faculdade de Enfermagem, Departamento de Enfermagem Hospitalar na Rede de Atenção em Saúde. Pelotas, Rio Grande do Sul, Brasil. ${ }^{2}$ Universidade Federal do Rio Grande do Sul. Programa de Pós-Graduação em Enfermagem. Porto Alegre, Rio Grande do Sul, Brasil.

\begin{abstract}
Objective: to describe and analyze the challenges and the possibilities of the return to the home in palliative care in the Brazilian and French scenarios.

Method: ethnographic study conducted in two hospitals, homes and medical-social establishments. Six people in palliative care, four family members and eight health professionals participated in the study. The data were organized through discursive mapping and analyzed from a cultural and Foucaultian perspective.

Results: to present the results, two categories were elaborated: Strategies for hospital discharge in palliative care and between the family, the state and justice: barriers to return home. It is evident that, in Brazil and in France, the return to the home is an event that faces resistance from the families. This fact is mainly related to the cultural conceptions that hospital palliative care units are places capable of providing comfort at the end of life, and difficult access to home care programs and services. In both countries, due to the complexity of hospital discharge, families and managers judicialize this process.

Conclusion: the return to the home in palliative care depends on the way death is signified in a culture, the family settings and the existence or not of a network of palliative care in the health systems of each country.
\end{abstract}

DESCRIPTORS: Death. Palliative care. Nursing. Home assistance. Cultural anthropology. Patient discharge. 


\section{É POSSÍVEL MORRER NO DOMICÍLIO? ANÁLISE DOS CENÁRIOS BRASILEIRO E FRANCÊS}

\section{RESUMO}

Objetivo: descrever e analisar os desafios e as possibilidades do retorno ao domicílio em cuidados paliativos nos cenários brasileiro e francês.

Método: estudo etnográfico realizado em dois hospitais, domicílios e estabelecimentos médicosociais. Participaram da pesquisa seis pessoas em cuidados paliativos, quatro familiares e oito profissionais de saúde. Os dados foram organizados por meio de mapeamento discursivo e analisados sob a perspectiva cultural e foucaultiana.

Resultados: para apresentação dos resultados foram elaboradas duas categorias: Estratégias para a alta hospitalar em cuidados paliativos e Entre a família, o Estado e a Justiça: entraves para o retorno ao domicílio. Evidencia-se que, no Brasil e na França, o retorno ao domicílio é um evento que enfrenta resistência por parte das famílias. Tal fato relaciona-se principalmente com as concepções culturais de que unidades hospitalares de cuidados paliativos são os locais capazes de proporcionar conforto no final da vida, e com o difícil acesso a programas e serviços de atenção domiciliar. Em ambos os países, em razão da complexidade da alta hospitalar, famílias e gestores judicializam esse processo.

Conclusão: o retorno ao domicílio em cuidados paliativos depende do modo como a morte é significada em determinada cultura, das configurações familiares e da existência ou não de uma rede de cuidados paliativos nos sistemas de saúde de cada país.

DESCRITORES: Morte. Cuidados paliativos. Enfermagem. Assistência domiciliar. Antropologia cultural. Alta do paciente.

\section{¿ES POSIBLE MORIR EN EL DOMICILIO? ANÁLISIS DE LOS ESCENARIOS BRASILEÑOS Y FRANCÉS}

\section{RESUMEN}

Objetivo: describir y analizar los desafíos y las posibilidades del retorno al domicilio en cuidados paliativos en los escenarios brasileño y francés.

Método: estudio etnográfico realizado en dos hospitales, domicilios y establecimientos médicosociales. Participaron en la investigación seis personas en cuidados paliativos, cuatro familiares y ocho profesionales de salud. Los datos fueron organizados por medio de mapeamiento discursivo y analizados bajo la perspectiva cultural y foucaultiana.

Resultados: para la presentación de los resultados se elaboraron dos categorías: Estrategias para el alta hospitalaria en cuidados paliativos y entre la familia, el Estado y la Justicia: trabas para el retorno al domicilio. Se evidencia que, en Brasil y en Francia, el retorno al domicilio es un evento que enfrenta resistencia por parte de las familias. Este hecho se relaciona principalmente con las concepciones culturales de que unidades hospitalarias de cuidados paliativos son los locales capaces de proporcionar confort al final de la vida, y con el difícil acceso a programas y servicios de atención domiciliaria. En ambos países, en razón de la complejidad del alta hospitalaria, familias y gestores judicializan ese proceso.

Conclusión: el retorno a domicilio en cuidados paliativos depende del modo en que la muerte es significada en determinada cultura, de las configuraciones familiares y de la existencia o no de una red de cuidados paliativos en los sistemas de salud de cada país.

DESCRIPTORES: Muerte. Cuidados paliativos. Enfermería. Asistencia domiciliaria. Antropología cultural. Alta del paciente. 


\section{INTRODUCTION}

The palliative care units are specialized environments for the care of people who present illness with no possibility of modifying treatment, whether they are at the end of life or not. They can be understood as spaces of rupture with the hospital, since they transform the organizational model, trying to answer the critics and questions about the way the dying were treated..$^{1-2}$ In these units, besides the differentiated furniture and structure, the relations take place in a very particular way. If in the other sectors there are closed and isolated spaces for the medical and nursing teams, in the palliative care units the staff remains in the same environment as the hospitalized ones. This separation is part of the disciplinary mechanisms that organize the hospital, which define, delimit and dispose of the way each one must act, in order to favor the actions of health professionals on the bodies. ${ }^{3}$

Palliative care units have been the place where the philosophy of palliative care has been developed primarily in Brazil and in other countries. Thus, one identifies the social construction of the notion that "good death" or worthy death can be provided by specialized teams that work in these places. ${ }^{4-5}$ In this sense, one of the aspects that has mobilized the teams of these units is hospital discharge. For such teams, when the control of signs and symptoms is obtained, the referral to be performed is the return to the home or to establishments that fulfill the social function of shelter, such as long-term care institutions for the elderly or specialized clinics.

This perspective is in line with the government policies developed in recent years that prioritize the space of the house as a possible territory for care, not only in situations where there is a possibility of cure, but also in the context of palliative care. In this line, the Family Health Strategy (ESF) stands out in Brazil; and in France, there is the National Palliative Care Plan (2015-2018), which has as one of its axes the favoring of such care in the home. Also in this country, institutions of long stay are considered spaces for the end of life. ${ }^{6}$

At this juncture, it is believed to be important to analyze the way in which the transition of people in palliative care from the hospital to the home has taken place. This is because the political strategies for end-of-life management have operated beyond the sense of reducing beds and optimizing hospital resources. They also presuppose the use of support services to the health system that can enable a dignified death, lived with the family, in the least painful way possible.

Although they are distinct countries in their political, social, cultural and economic constitutions,

Brazil and France are approaching in elements that are related to the elaboration of public policies of health. Many of the Brazilian proposals for health care are inspired by European models, such as the Advance Directives Model (ADM). In France, Law 2016-87 or Loi Claeys-Leonetti, which had its first version in 2005 , deals with the rights of people with life-threatening diseases. This law advocates the strengthening of palliative care in the health services of France and recommends that the subjects elaborate advance directives of will in case of diseases without possibility of cure. ${ }^{7}$ This document is used when the person no longer can verbally express their desires.

In Brazil, in 2012, the Federal Medical Council approved Resolution 1,995/12, which indicates the development of ADM and recommends palliative care as a therapeutic option for the end of life, similar to the French model. ${ }^{8}$ Thus, it seems interesting to look at how the policies for end-of-life governance are being implemented in Brazil and France, not with the aim of positivizing one system over another, but to point out the challenges and possibilities that emerge from each scenario.

In view of the above, this article presents the following guiding question: What are the challenges and possibilities for returning people to palliative care? To answer this, the objective was: to describe and analyze the challenges and possibilities of the return to the home of people in palliative care in the Brazilian and French scenarios. 


\section{METHOD}

It is an ethnographic study, supported theoretically in two fields of study: Anthropology of Health and Cultural Studies. Ethnographic studies have as a characteristic the observation and description of human groups, their behaviors, their relations with institutions and values from a certain culture. ${ }^{9-10}$ The research scenarios were two public hospitals, one French and one Brazilian, in addition to the place to which the participants returned after being discharged. The choice for conducting an ethnographic study in the two countries was because the approximations between their public health policies were identified, as already mentioned. In addition, during the $\mathrm{PhD}$ course, the main author of this study made a technical visit to the French service. From this encounter emerged questions about the limits of the palliative care teams of that country to effect the return to the home of patients at the end of life, a situation like that found in Brazilian services.

In Brazil, the palliative care unit has seven beds and is in a public hospital in the city of Porto Alegre/RS. In France, the unit has ten beds and is part of a public hospital in Grenoble, a city located in the south-east of France. The immersion time in the field, in France and in Brazil, was 24 months, between October 2014 and October 2016.

Regarding the negotiations and approaches to carry out the research, in the Brazilian scenario, the fact that the main researcher of the study had a teaching internship with her supervisor at the palliative care unit in 2012 and 2014 favored the process of "acceptance" to accompany the professionals in the daily work. Still in this scenario, the approach to people in palliative care and their families was as follows: the researcher was in the hospital as a nurse accompanying the team for a research on "the difficulties and facilities of being in the hospital and be at home". In the course of the conversations, the patients or their relatives approached the worries about the end of life in some way. Thus, after one or two visits, the invitation to participate in the study was made.

Still on this aspect, in France, the main limitation was the incomprehension, on the part of health professionals and some patients, about the nurse's role as a researcher. As the identity of this professional in this country is still linked to the development of specific techniques and procedures in the area, the professionals thought that the researcher would travel by services to provide care to patients. This was not possible for two reasons: 1) the Brazilian diploma is not valid in France and 2) care was not the purpose of the research. However, as in Brazil, the researcher helped the teams to perform some activities, such as the patients' body hygiene, in order to encourage interaction and acceptance among health professionals. In relation to patients, the approach used to negotiate participation in research was the same as in Brazil.

In relation to the health professionals, those who participated in the organization of the return to the home were selected, namely: nurses, doctors, social workers and auxiliary or nursing technicians. People in palliative care were selected from previous contact with health professionals and from medical records.

The inclusion criteria for the selection of health professionals were: to be part of the multiprofessional team of the Palliative Care unit, excluding professionals who were on leave in the period of data collection. Eight professionals were invited, four in each country, with no refusal or withdrawal. For the selection of people in palliative care, inclusion criteria were considered: age equal to or greater than 18 years, and prospect of returning to the home during hospitalization. In the Brazilian scenario, people who did not live in the city of Porto Alegre were excluded, and in France, those who did not live in Grenoble. Three patients were selected in each country, without refusal or withdrawal.

In Brazil, when the relative was included as a participant, the one who was most present during hospitalization was selected. In France, the person of trust referred by the patient in his DAV was chosen. The inclusion of family members was at the invitation of researchers in situations in which the patient had no clinical conditions (fatigue, pain, dyspnea) to respond to the study, and when 
spontaneously expressed their interest in participating in the interview. Thus, three Brazilian relatives and one French family were included.

Because these patients were not only in palliative care but also in the end-of-life, the number of informants was not privileged, but it was sought to interact as much as possible with them, in order to better data that emerged from field inputs.

The social research techniques used were participant observation, the semi-structured individual interview and the field diary. Participant observation was systematized based on the relationships between health professionals, people in palliative care and their families. It was observed the scenario in which the subject in palliative care was, the hospital environment and the place where he followed discharge. Observational visits, both in the hospital and at home, occurred during the day, according to prior agreement with the staff, people in palliative care and their families. On average, during the two years of immersion in the field, the principal investigator of the study stayed three days of the week in the units between $8 \mathrm{am}$ and $5 \mathrm{pm}$, the rest were reserved to carry out the home visits. Tuesday was the day of the week reserved for team monitoring, since on that day, both in Brazil and in France, multidisciplinary meetings are held to discuss the "cases" of the unit.

The field diary was elaborated from the notes recorded in the notebook during the observations. The semi-structured individual interview was carried out when there was a need to deepen aspects not elucidated during the observations. In Brazil, one of the three people accompanied was able to respond. In France, the three people who were accompanied were able to be interviewed. The interviews, whose questions dealt with the organization of the team and the family for the return to the home, had a varied duration between 30 and 40 minutes, being recorded in audio through a digital recorder and then transcribed.

The empirical material was organized according to the discursive approach to which the participants' statements belonged, thus constituting the corpus of the research. Discursive mapping was carried out, which allowed the delimitation of the elements that cross and constitute the positions of relatives, people in palliative care and health professionals, in the relationships that are established in the organization of the return to the home. This mapping took place through tables that organize the analytical units, as used in other Cultural Studies. ${ }^{11-12}$

The corpus of the research was submitted to cultural analysis, with Foucaultian theorizations. In this analytical process, the evaluations were elaborated at the interface of the Cultural, anthropological and Foucaultian Studies, based on the articulation of the following theoretical notions: governmentality and medicalization. ${ }^{13-15}$

During all stages of the research, the national and international research guidelines involving human beings were respected. In the case of Brazil, the norms established in Resolution 466/2012 of the National Health Council were followed.

In France, according to the Code of Public Health (CSP) in force in the period of the research, it is not necessary for participants in non-interventional studies, in the case of ethnographic studies, to sign a free and informed consent form, since they do not incur risks and health problems. In these cases, it is directed to researchers who request only verbal consent of the participants. The verbal consent of all the participants was requested, both in the hospital context and in the home context. In addition, for the accomplishment of the research, was obtained written authorization of the heads of the hospital and the palliative care unit.

To ensure participants' anonymity, they were identified by pseudonyms. For people in palliative care were adopted fictitious names of historical personages of Brazil and France. Family members were identified as follows: caretaker andfictitious name of the person in palliative care. Health professionals were given the following denomination: "professional+country of origin and identifier number. 


\section{RESULTS}

All health professionals interviewed were women, four were French, and four were Brazilian. The time spent in the palliative care area ranged from two to 31 years. Because it was a study carried out in small units and easy to recognize the subjects, it was sought not to identify the profession in the excerpts of speech of these participants. Regarding the patients, two women, Tereza Cristina and Isabel, aged 60 and 64 years old, were followed in Brazil; and a man, Pedro, 61 years old. The period between the beginning of follow-up and death ranged from 15 to 45 days. In France, two women were also accompanied, Marie and Jeanne, aged 83 and 71, and a man, Louis, 73. Follow-up time ranged from 11 to 40 days. All patients were oncological.

As far as the family members were concerned, they were interviews three Brazilian and one French, being two daughters and two wives. Of the six patients, five returned home, and one, French, was referred to a social-medical establishment that houses elderly people with dependency, a place that became their home until the moment of death. Two patients, one Brazilian and one French, returned after a second hospitalization to the daughter's and daughter-in-law's home, respectively, due to an increase in dependence on basic life activities. It is noteworthy that the interviews in French were freely translated by the main author of this article.

\section{Strategies for hospital discharge in palliative care}

The strategies to effect discharge in palliative care in Brazil are through the attempts of communication between the hospital and the other services that make up the Network of Attention in Health: Whenever it demands this interlocution with the network, it ends up being for the social service to account. In some cases, what I try to do is to insert the other professional along. In some cases I contact the network, which have some more specific demands of nursing care. I've already asked the nurse to talk to the nurse in the unit. Hardly, we get doctors to get more involved in this (Brazilian Professional 1).

Of the three people followed in the Brazilian scenario, none were counter referred: in one situation, due to lack of communication between the hospital staff and the ESF team; in the other two, there was no link between families and teams in the territory.

In the absence of a specific care line for people at the end of life, they end up transiting between one emergency service and another. In these comings and goings, the family comes to know and to meet the needs of the patient: And then what happened: my sister turned from here, from there, from there and from here, and from my other sister-in-law. They contacted two people who had beds, one was borrowed, the other, in principle, available to be installed at home today, from four o'clock [afternoon] (Pedro's wife).

My son-in-law took me home. He's the one who spends his time working down that ladder [referring to the staircase to access the home] (Isabel).

In Brazil, families reorganize their homes and, thus, the person in palliative care can return to the home. When return is not possible, long-term institutions are the alternative: Most institutions that support people with a high dependency are very expensive, so it is up to the family to account for this expense, because most of the elderly people we meet here when they are discharged are very dependent on care. And most institutions, which do not even welcome those who are dependent on care, do not host an elderly person who has a dependency (Brazilian Professional 1).

In France, where many elderly people live alone, health-funded professionals work directly at home, helping the sick or care-giving families: In France, there are various aids of different natures 
for the return and maintenance at home, whether providing material, caretakers or help at home, technical assistance, tele-alarm, alert system and meal delivery. All these are help that we will use and request, which are not financial aid, but which are concrete aid that will be carried out in the person's home (French professional 1).

If, however, return to the home is not possible, medical-social establishments are considered as an alternative to de-hospitalization: And from the state he is in today, it is no longer possible for him to return to our home, although the conversations I had with professionals who could work in our house. (Louis' Wife). When you are in a long-term care facility for the elderly or in the long-term care units, you have a part that is paid by Sécurité Sociale for everything that is taken care of. For all the rest, the hospitality, the food, the handling of the patient, the family must pay or the patient. And in most situations, patients cannot afford to pay (French professional 1).

\section{Between the family, the State and Justice: barriers to return home}

Among the obstacles to return to the home, the family, the State and Justice stand out. The family, as a facilitator for the discharge, also limits it: In fact, here, the biggest difficulties that people have of the patient going home are related to the family itself in the sense of caring difficulties. How will they care? How will you have a hospital bed, a torpedo of $\mathrm{O}_{2}$ (Brazilian Professional 3). I'm terribly afraid he dies at home. I'm really scared. I do not want this to happen, but it's not we who rule, right!? We do not command. If God wants to, what am I going to do? That's why I did not want to bring him home. [...] I have the impression that losing your loved one in your home must be so traumatic afterwards. So traumatic, you know? I think it's more traumatic than if you lose in the hospital (Pedro's wife).

The limitations the family imposes are related to responsibilities and care. When people enter the final phase of life, physical changes often bring about shame on the part of the sick and fear on the part of family members, who do not know how to react at the time of death. In Brazil and in France, fear is related to death in the space of the house: There are families that are completely against [the return to the home], because they are afraid. So it is a whole process of... it is fear of the unknown. Fear of the unknown. They are afraid that the end will be traumatic, that the person will be short of breath. Then we explain that there are treatments and that we can achieve a serene end of life, which has people who sleep. And it also has the difficulty of homes that cannot be adapted, with stairs, with very small pieces, where people cannot put a hospital bed, for example (French professional 3).

In France, the main difficulty in relation to hospital discharge concerns the length of hospitalization and the cost of establishments that are alternatives to the home. In that country, palliative care units are classified as short stay/stay services. Thus, these are units financed by the activities performed and by the time people remain hospitalized: The great, great difficulty, I think it's T2A [Tarification des Activités - charge of activities, free translation $]^{*}$ that causes us to have an average length of stay of 14 days. And that at the end of 14 days, we have the impression of throwing the patient out. That's it, too. It is a great difficulty. Because if we had a DMS [Durée Moyenne de Séjour - mean length of stay, free translation] which was larger and had no T2A, then we would have two beds, one being an average stay and not a short stay. And there would be many patients with whom we would stay until the end (French professional 3 ).

A final aspect that challenges the return to the home concerns the process of judicialization of health. In Brazil, when they are faced with the possibility of returning home, unable to care for

\footnotetext{
*Tarification des Activités (T2A) - In France, short-term hospital services, such as palliative care units, are financed through the charging of hospital activities (T2A), according to the activities carried out and the average length of hospitalization (Durée Moyenne de Séjour - DMS). In these sectors, hospitalizations lasting up to 12 days are financed according to the activities developed. In hospitalizations that last less than 4 or more than 13 days, the institution may not receive the full amount by procedure.
} 
and provide the support they have as the "ideal" for the care of the family member at the end of life, it is common to resort to Justice to guarantee the permanence in the hospital and thus ensure continuity of assistance: I arrived at the unit around 9:05. Upon entering, I greet the people there. I stand in a corner waiting for the team meeting. In the corridor, I witnessed a little discussion between the oncologist and other medical residents. They discussed the situation of a patient named Teresa Cristina. The doctor reports that the patient's daughter had filed a court order for Teresa Cristina to stay in the hospital and that, moreover, her daughter had released photos of the hospital emergency in a social network. [...] The meeting was attended by doctors, nurses and a nutritionist. The doctor leads the discussions. She introduces the doctors present and then the nurses. The meeting begins when she asks the nurse to present the situation of each hospitalized patient. The nurse presents the situation of the first patient, Mrs. Teresa Cristina. The team discusses the fact of photos posted on Facebook. They begin to make a tone of indignation. On the other hand, one of the doctors says that one must take care of this family as well. That the reaction of the girl, daughter of Teresa Cristina, may have been the way she expressed all the suffering of seeing her mother dying almost eight years ago. Another professional agrees with him, talking about the behavior of young people and the relationship with social networks. Both say that this family is experiencing an exhaustion of the illness of Teresa Cristina, which lasts for eight years and that at this moment seems to come to an end [...] (Field Diary, May 26, 2015).

In France, the process of prosecution is reversed: hospitals go to court to request that families care for sick and abandoned elderly people in these establishments. To exemplify the complexity of these situations, in the hospital where the research was carried out, there is a specialized team to promote hospital discharge. This service is known as Complex Discharges Units (USC). It is composed of multiprofessional team that travels by the institution to accelerate the process of discharge and, when necessary, to bring to justice: I arrived at the Dauphiné Pavilion around 8:50 a.m. for the meeting with Monsieur X, responsible for the Unité de Sortie Complexe - USC. At the meeting, he explains that the goal of the team's work is to reduce the average length of hospital stay, and to facilitate or accelerate the hospital discharge process. An indirect objective is the evacuation of beds so that patients who are on stretchers can be better received. According to him, on average, eight patients are hospitalized on stretchers in the corridors of each unit. After the assaults of the USC team, that number has declined. For him, as responsible for the team and as agent that implements the hospital proposal, the projection is not to have patients in the corridors and relieve the emergency service. Among the difficulties in the team's work, he reports on the problem of framing the whole team, the family and the patient in the same life project. He says that the cases of elderly people with dementia turn out to be more difficult to organize, especially by the limitation of finding a place in a socialmedical establishment. In general, the waiting time to access any of these establishments ranges from one to three years. [...] In situations where the family refuses to take the patient home, insisting on hospitalization, the team uses legal tools to persuade families, especially children, to take care of their parents (Field diary, January 12, 2016).

\section{DISCUSSION}

In this study, Primary Health Care appeared as a strategy that favors the return and permanence of people at home. However, not all people in palliative care can benefit from this follow-up. "Despite being a system based on principles of territorialization and coordination of actions and exist for several decades, there is still fragility in the integration between Primary Health Care and specialized care under the Unified Health System (SUS)." ${ }^{16: 218}$ Some limitations include the absence of teams in some 
territories, the lack of communication between the hospital services and those of PHC, and the lack of knowledge of professionals about the flow of referrals in the network.

In the Brazilian scenario, besides being responsible for care, the family must provide the means to do so. Due to the degree of dependence and the high demand for care, especially in the final stages of life, family members would need support from home-based services, which can resolve doubts and provide support when needed. ${ }^{17}$ However, it is possible to note fragility regarding the resources made available by SUS to subsidize end-of-life care at home. With the introduction of equipment, medications, dressing dressings and other technologies, health, pain control, wound prevention and the reduction of suffering go through the use of these resources. ${ }^{14}$ Thus, while on the one hand the use of health technologies has medicalized the vital processes, on the other hand, it has promoted the relief of suffering and the promotion of less painful death.

Thus, it is believed that using families as a strategy that favors the return to the home can be interesting, if there is support for those who care. It is identified that the State mobilizes and leads health professionals to empower families for end-of-life care. In Brazil, given the size of the population and the capacity to offer services, professionals intervene in a timely manner, advising families. The professionals are the experts about body care. Because they cannot intervene with large numbers of people, they "empower" their families and rules on how care is to be done. From time to time, visits are made at home, in order to monitor and correct what has not been done according to the protocols. In this way, it is noticed that, even in the space of the house, people remain under the control of medical practices. ${ }^{18}$

In situations where return to the home is not possible, medical and social establishments, also called long-stay institutions for people with or without dependency, have been a growing alternative, especially in the French scenario. These establishments become the living place of care-dependent adults and seniors. In France, they are financed by the public health system, except for those who offer personalized care, thus becoming costlier. ${ }^{19}$ In this scenario, it can be seen that the end of life continues to be a medicalized process conducted by health professionals, even in situations where patients and families are given access to the philosophy of palliative care.

In the speech of professionals, especially those of the French, it is evident how the numbers govern the logic of the health market. In this sense, the concept of numerality (neologism) becomes productive in order to discuss how statistical knowledge determines conduct in the field of education and in the area of health, in the contemporary world. This concept, inspired by the notion of governmentality, refers to "the combination of the arts of governing and the practices and norms surrounding quantification, measurement, accounting, and serialization, which guide the enunciative production of social practices in the media institutional". ${ }^{20: 416}$ It is necessary to show numbers and values in order to finance the services and to compose the statistics and records of the State, which serve to show the effectiveness of the actions proposed by the Government to manage life and death. As soon as the right to "good death", as well as the right to health, became the object of consumption, the State needed to collect and classify data in order to indicate the results of the implemented policies. In this understanding, people become subjects of law and objects of science, since they require the interventions made possible by technology, while being capable of identification and classification, in order to legitimize the conduct of the State. ${ }^{21}$

Finally, perceiving health as a right, and understanding themselves as subjects of rights, people seek justice when they do not see their health needs met. The judicialization of health refers to the way justice happens to intervene in the decisions of a field that, until then, did not belong to it. Courts are used to access treatments, examinations and hospitalizations. ${ }^{22}$ Today, trying to de-medicate some processes, such as dying, "one cannot get out of medicalization and all efforts in this direction refer to medical knowledge". ${ }^{23: 185}$ This is because, even when trying to give back to the subjects the right to 
lead the end of their lives, the field of health finds other ways to appropriate this stage of life. Norms and standards of behavior are created for this period, mechanisms are developed to control pain, to remove suffering, which brings people closer to what Foucault called the collective medicalization apparatus: the hospital. ${ }^{23}$

It is believed that the study has limitations that relate to the time factor. Probably, if there was time to accompany people for a longer period, it would be possible to grasp other elements and other specificities of the return of palliative care to the home. However, researching the end of life requires flexibility and adaptation to the time of dying people and their families, which may be longer and disabling for some than for others. Despite the limitations, the study contributes to the area of nursing and public health, insofar as it describes the challenges present in the operationalization of care strategies with people with illnesses that are not curable and their families. It points out elements that can be explored, aiming the construction of a line of care for the end of life.

\section{CONCLUSION}

In Brazil, the public health policies see the home as a powerful place for care. The family must take care of those who are at the end of life. The services of the health care network should be articulated to facilitate the movement of people according to their health needs. Despite this, the hospital still fails to carry out the reference and counter-referral process. People in palliative care return home with their families because the hospital needs the beds, but they are left homeless, having to bear the costs for the purchase of materials and devices necessary for the care and control of the frequent symptoms at the end of life.

In France, the home is also the place par excellence for the end of life. The State has financial resources to assist in the hiring of caregivers and finances the transformation of households in an environment that has practically the same conditions as a hospital bed. Although there is investment and support, families do not feel comfortable to receive a person at the end of life. In this way, medicosocial establishments are places where individuals are institutionalized and end their days.

Thus, amid this struggle between the different knowledges and powers, the relations between life and death within the hospital and the home become. However, far beyond the question of the place where the end of life occurs, it is here the senses given to this event. These senses have a strong crossing of the discourses of science, technology, medical knowledge and legal knowledge. They guide the desires of people who are at the end of life, establishing what may or may not be a worthy death.

\section{REFERENCES}

1. Cordeiro FR, Kruse MHL. Production of an end-of-life curriculum vitae through the pedagogical apparatus of the media. Interface (Botucatu) [Internet]. 2015 [cited 2017 Aug 28]; 19(55):1193205. Available from: http://dx.doi.org/10.1590/1807-57622014.0199

2. Castra M. L'émergence des soins palliatifs dans la médecine, une forme particulière de militantisme de fin de vie. Quaderni [Internet]. 2012 [cited 2017 Nov 28];68:25-35. Available from: https:// dx.doi.org/10.1016/j.medpal.2015.08.007

3. Baptista MKS, Santos RM, Duarte SJH, Comassetto I, Trezza MCSF. The patient and the relation between power-knowledge and care by nursing professionals. Esc Anna Nery [Internet]. 2017 [cited 2018 Mar 29];21(4):e20170064. Available from: http://dx.doi.org/10.1590/2177-9465ean-2017-0064. 
4. Alonso JP. The Construction of Dying as a Process: the Management of Health Professionals at the End of Life. Univ. Humanist [Internet]. 2012 [cited 2017 Sep 14];74:123-44. Available from: http://www.scielo.org.co/pdf/unih/n74/n74a07.pdf

5. Menezes RA, Barbosa PC. The construction of a "good death" at different stages of life: reflections on the palliative care approach for adults and children. Ciênc Saúde Coletiva [Internet]. 2013 [cited 2017 Aug 25];18(9):2653-62. Available from: http://dx.doi.org/10.1590/S1413-81232013000900020

6. Ministére des Affaires sociales, de la Santé et des Droits des femmes. Plan national trienal pour le développement des soins palliatifs et l'accompagnement en fin de vie - 2015/2018. [Internet]. Paris;2015 [cited 2017 Nov 26]. Available from: http://solidarites-sante.gouv.fr/IMG/ pdf/031215_-_plabe56.pdf

7. Devalois B. Loi du 2 février 2016 : un droit à la sédation à visée bien traitante, pas à visée euthanasique. Médecine Palliative [Internet]. 2016 [cited 2017 Dec 02];15(1):1-3. Available from: https://dx.doi.org/10.1016/j.medpal.2016.02.001

8. Conselho Federal de Medicina (BR). Resolução n. 1.995, 09 de agosto de 2012: Dispõe sobre as diretivas antecipadas de vontade dos pacientes [Internet]. Brasília (DF): CFM; 2012. [cited 2017 Nov 26]. Available from: http://www.portalmedico.org.br/resolucoes/cfm/2012/1995_2012.pdf

9. Geertz C. The interpretation of cultures. New York: Basic Books;1973.

10. Damico J. Gestão da vida a partir do esporte e lazer em Grigny Centre - França. Movimento [Internet]. 2012 [cited 2017 Dec 02];19(1):11-31. Available from: https://doi.org/10.22456/19828918.29826

11. Cordeiro FR, Kruse MHL. The right to die and power over life: knowledge to govern the bodies. Texto Contexto Enferm [Internet]. 2016 [cited 2017 Dec 10];25(2):e3980014. Available from: http://dx.doi.org/10.1590/0104-07072016003980014

12. Ferreira MS, Traversini CS. A análise foucaultiana de discurso como ferramenta metodológica de pesquisa. Educ Real [Internet]. 2013 [cited 2016 Dec 10];38(1):207-26. Available from: http:// dx.doi.org/10.1590/S2175-62362013000100012

13. Foucault M. The birth of biopolitics: lectures at the College de France, 1978-79. New York, US: Palgrave Macmillan;2008.

14. Illich I. Medical Nemesis: the expropriation of health. New York, US: Pantheon Books;1975.

15. Gaudenzi P. Biopolitical mutations and discourses about normality: foucaultian actualizations in the biotechnological age. Interface (Botucatu) [Internet]. 2017 [cited 2017 Nov 12];21(60):99-110. Available from: http://dx.doi.org/10.1590/1807-57622015.0870

16. Protasio APL, Silva PB, Lima EC, Gomes LB, Machado LS, Valença AMG. Evaluation of the reference and counter-reference system based on the responses of the primary care professionals in the first external evaluation cycle of pmaq-ab in the state of Paraíba. Saúde debate [Internet]. 2014 [cited 2017 Oct 15];38(spe):209-20. Available from: http://dx.doi.org/10.5935/0103-1104.2014S016

17. Marcucci FCl, Perilla AB, Brun MM, Cabrera MAS. Identification of patients referred to Palliative Care in the Brazilian Family Health Strategy: an exploratory study. Cad Saúde Colet [Internet]; 2016 [cited 2017 Dec 14];24(2):145-52. Available from: http://dx.doi.org/10.1590/1414-462X201600020012

18. Oliveira SG, Kruse MHL. Better off at home: safety device. Texto Contexto Enferm [Internet]. 2017 [cited 2017 Dec 03];26(1):e2660015. Available from: http://dx.doi.org/10.1590/010407072017002660015

19. Desforges $C$, Montaz L. Soins palliatifs et précarité : l'impossible équation ? Étude sur l'hébergement social en unité de soins palliatifs. Médecine Palliative [Internet]. 2015 [cited 2017 Dec 03];14(1):319. Available from: https://dx.doi.org/10.1016/j.medpal.2014.10.002 
20. Bello SEL, Sperrhake R. Educação e risco social na curricularização do saber estatístico no Brasil. Acta Scientiarum. Education. [Internet]. 2016 [cited 2018 Mar 28];38(4):415-24. Available from: https://dx.doi.org/10.4025/actascieduc.v38i4.27882

21. Latour B. We have never been modern. Cambridge, US: Harvard University Press;1993.

22. Alonso JP. El derecho a una muerte digna en Argentina: la judicialización de la toma de decisiones médicas en el final de la vida. Physis Rev Saúde Coletiva [Internet]. 2016 [cited 2018 Mar 29]; 26(2):569-89. Available from: http://dx.doi.org/10.1590/S0103-73312016000200012

23. Foucault M. Crise da medicina ou crise da antimedicina. Verve [Internet]. 2010 [cited 2016 Dec 20];18(1):167-94. Available from: https://revistas.pucsp.br/index.php/verve/article/view/8646 


\section{NOTES}

\section{ORIGIN OF THE ARTICLE}

Article extracted from the thesis - The return to the home in palliative care: interface of the Brazilian and French scenarios, presented to the Post-graduate Program in Nursing of the Universidade Federal do Rio Grande do Sul, in 2017.

\section{CONTRIBUTION OF AUTHORITY}

Study design: Cordeiro FR, Kruse MHL.

Data collect: Cordeiro FR

Data analysis and interpretation: Cordeiro FR, Kruse MHL.

Discussion of the results: Cordeiro FR, Kruse MHL.

Writing and / or critical review of content: Cordeiro FR, Kruse MHL.

Review and final approval of the final version: Cordeiro FR, Kruse MHL.

\section{ACKNOWLEDGMENTS}

To Noelle Carlin, Ph.D, of the Centre Hospitalier Universitaire Grenoble Alpes, Grenoble-France

\section{FUNDING INFORMATION}

The research was funded by the Commission for the Improvement of Higher Education Personnel (CAPES) and by the National Council for Scientific and Technological Development (CNPq).

\section{ETHICS COMMITTEE IN RESEARCH}

Approved by the Ethics Committee in Research with Human Beings of the hospital de clinicas de Porto Alegre, Opinion 1,072,851 and Certificate of Presentation for Ethical Appreciation (CAAE): 43747015.5.0000.5327.

\section{CONFLICT OF INTEREST}

No any conflict of interest.

\section{HISTORICAL}

Received: December 22, 2017.

Approved: April 13, 2018.

\section{CORRESPONDENCE AUTHOR}

Franciele Roberta Cordeiro

franciele.cordeiro@ufpel.edu.br 